\title{
PNA-Mediated Purification of PCR Amplifiable Human Genomic DNA from Whole Blood
}

BioTechniques 23:512-517 (September 1997)

\author{
Corina Seeger, Hans-Georg \\ Batz $^{1}$ and Henrik Ørum \\ PNA Diagnostics A/S \\ Copenhagen, Denmark \\ ${ }^{1}$ Boehringer Mannheim $\mathrm{GmbH}$ \\ Tutzing, Germany
}

\section{INTRODUCTION}

The development of powerful nucleic acid amplification methods such as polymerase chain reaction (PCR) has contributed immensely to the emerging field of nucleic acid diagnostics. Most of these methods utilize enzymes that have been shown to be inhibited by substances present in many, if not all, biological samples $(7,11,15,19)$. Hence, methods that facilitate the rapid purification of nucleic acids from biological samples in a form suited for subsequent amplification are of considerable interest. We have previously shown that peptide nucleic acid (PNA) oligonucleotides carrying six histidine residues can be used to purify target nucleic acids by Ni-NTA affinity chromatography (22) and that biotinylated PNAs in combination with streptavidin-coated magnetic beads can be used to purify Chlamydia trachomatis genomic DNA directly from urine samples (1). This "purification by hybridization" approach offers a number of advantages compared to traditional nucleic acid purification methods, such as, for example, extractions in organic solvents or reversible unspecific binding to solid supports. First, it utilizes the unique ability of nucleic acids to undergo basespecific hybridization, thereby significantly reducing the chance of co-purification of unwanted non-nucleic acid substances that can inhibit subsequent amplification reactions. Second, purification by hybridization removes unrelated bulk nucleic acids that can gener- ate a substantial background in a subsequent amplification process. However, a drawback of purification by hybridization is that it is not a generic method, i.e., it requires knowledge of a target sequence and synthesis of a dedicated capture oligonucleotide for each different target nucleic acid.

Short PNAs (9-mer and 10-mer) composed exclusively of pyrimidine residues form triplexes of unprecedented thermostability with complementary nucleic acids $(4,5,13)$. Being short, their target sequence will be prevalent in large nucleic acids. Thus, we reasoned that such PNAs could be used as generic capture probes for the purification of large nucleic acids.

We report here that a biotin-tagged PNA T7 can be used to efficiently purify human genomic DNA from whole blood by a simple and rapid procedure. Moreover, we show that this purification procedure effectively removes inhibitors of the PCR, which are otherwise present in the unpurified blood samples.

\section{MATERIALS AND METHODS}

Blood samples from twelve donors were obtained by venapuncture in either EDTA buffer, Na-citrate buffer or heparin. Aliquots were stored at $-20^{\circ} \mathrm{C}$. The bisPNA $\mathrm{T}_{7}$ was synthesized at PNA Diagnostics A/S (Copenhagen, Denmark) as previously described (10).

The thermostability (melting temperature $\left[\mathrm{T}_{\mathrm{m}}\right]$ ) of the bisPNA $\mathrm{T}_{7} / \mathrm{DNA}$ 
$\mathrm{A}_{7}$ triplex was determined spectrophotometrically at $260 \mathrm{~nm}$ using an $\lambda-2$ Spectrophotometer (Perkin-Elmer, Norwalk, CT, USA) equipped with a Peltier thermal block. The hybridization buffer contained $100 \mathrm{mM} \mathrm{NaCl}, 10$ $\mathrm{mM} \mathrm{Na} \mathrm{HPO}_{4}, \mathrm{pH}$ 7.0, 0.1 mM EDTA, $1.5 \mu \mathrm{M}$ of PNA and $1.5 \mu \mathrm{M}$ of DNA.

\section{Sample Preparation Procedure}

Lysis. The blood sample (stored at $-20^{\circ} \mathrm{C}$ ) was thawed at room temperature (RT) and vortex mixed for 2-3 s. When using up to $100 \mu \mathrm{L}$ of blood, the sample was mixed with $100 \mu \mathrm{L}$ of lysis buffer (100 mM Tris-HCl, $\mathrm{pH} 8.5,50$ $\mathrm{mM} \mathrm{KCl}, 6 \mathrm{mM} \mathrm{MgCl}_{2}, 0.02 \%$ Triton ${ }^{\circledR}$ $\mathrm{X}-100$ and $1 \mathrm{mg} / \mathrm{mL}$ proteinase $\mathrm{K}$ [Boehringer Mannheim, Mannheim, Germany; added just before use]), 100 pmol of biotinylated bisPNA $\mathrm{T}_{7}$ and water to a final volume of $200 \mu \mathrm{L}$. When using more than $100 \mu \mathrm{L}$ of blood, the sample was mixed with 500 $\mu \mathrm{L}$ of lysis buffer, 100 pmol of biotinylated bisPNA $\mathrm{T}_{7}$ and water to a final volume of $1 \mathrm{~mL}$. After mixing, the sample was incubated at $55^{\circ} \mathrm{C}$ for 15 $\min$, then at $100^{\circ} \mathrm{C}$ for 10 min to inactivate the proteinase $K$ (3). The sample was then centrifuged at $12000 \times g$ for 5 min to pellet cellular debris (when less than $25 \mu \mathrm{L}$ of blood is used, the centrifugation step can be omitted). Finally, the supernatant was transferred to a new microcentrifuge tube.

Capture onto magnetic beads. The supernatant from the lysis step was incubated at RT for $10 \mathrm{~min}$ to allow the PNA to hybridize to its target sequences. Twenty micrograms of paramagnetic streptavidin-coated particles (Dynabeads ${ }^{\circledR}$ M-280; Dynal AS, Oslo, Norway) (washed twice in $200 \mu \mathrm{L}$ of wash buffer [20 mM Tris- $\mathrm{HCl}, \mathrm{pH} 8.3$, $100 \mathrm{mM} \mathrm{KCl}, 3 \mathrm{mM} \mathrm{MgCl}_{2}, 0.1 \%$ Zwittergent] and resuspended in $50 \mu \mathrm{L}$ wash buffer) were added to the sample followed by a 10-min shaking at 1200 rpm at RT to allow the bisPNA $\mathrm{T}_{7} /$ DNA complex to bind to the streptavidin-coated particles. The magnetic beads were pelleted with a Magnetic Beads Concentrator (Dynal AS) and washed twice in $200 \mu \mathrm{L}$ of wash buffer. After the second wash, the magnetic beads were resuspended in $20 \mu \mathrm{L}$ of water.

\section{PCR Procedure}

PCR amplifications were carried out in a final volume of $100 \mu \mathrm{L}$ containing $10 \mathrm{mM}$ Tris- $\mathrm{HCl}$ ( $\mathrm{pH} 8.3$ ), either 1.5 $\mathrm{mM} \mathrm{MgCl} 2$ (p62 plasmid and factor IX target) or $2.25 \mathrm{mM} \mathrm{MgCl}_{2}$ (cystic fibrosis transmembrane conductance regulator [CFTR] target), $50 \mathrm{mM} \mathrm{KCl,} 200$ $\mu \mathrm{M}$ dATP, dGTP and dCTP, $600 \mu \mathrm{M}$ dUTP, either $10 \mathrm{mM}$ Digoxigenin (Dig) 11-dUTP [Boehringer Mannheim]) (CFTR and factor IX target) or no Dig (p62 plasmid target), either $0.5 \mu \mathrm{M}$ of each primer (p62 plasmid) or $1 \mathrm{mM}$ of each primer (factor IX and CFTR) and $5 \mathrm{U}$ of Taq DNA Polymerase (Boehringer Mannheim).

All 20- $\mu$ g magnetic beads containing the template DNA from the purification procedure were added to the reaction mixture. The PCRs were overlaid with 2 drops of mineral oil (Sigma Chemical, St. Louis, MO, USA). A MiniCycler ${ }^{\mathrm{TM}}$ Thermal Cycler (MJ Research, Watertown, MA, USA) was used for amplification.

Amplification of the p62 plasmid. The plasmid p62 (21) served as template for the generation of a 192-bp product using the following primers; CS10: 5'-ACC AAA ATC CCT TAA CGT GA-3' and CS11: 5'-TGC TGA AGC CAG TTA CCT TC-3'. The PCR cycle conditions were $94^{\circ} \mathrm{C}$ for $5 \mathrm{~min}$ followed by 35 cycles of $94^{\circ} \mathrm{C}$ for 1 $\min ; 50^{\circ} \mathrm{C}$ for $1 \mathrm{~min}$; and $72^{\circ} \mathrm{C}$ for 1 min. The PCR ended with an incubation for $5 \mathrm{~min}$ at $72^{\circ} \mathrm{C}$.

Amplification of the CFTR gene. Purified human genomic DNA served as template for the generation of a 312bp product from the CTFR gene using the following primers; $\triangle F 508$ back-3: 5'-GCA GAG TAC CTG AAA CAG GAA GTA T-3' and $\triangle$ F508wt-4: 5'CAT CAT AGG AAA CAC CAA AGA TGA T-3'. The PCR cycle conditions were $94^{\circ} \mathrm{C}$ for $5 \mathrm{~min}$ followed by $40 \mathrm{cy}$ cles of $94^{\circ} \mathrm{C}$ for $30 \mathrm{~s} ; 60^{\circ} \mathrm{C}$ for $30 \mathrm{~s}$; and $72^{\circ} \mathrm{C}$ for $30 \mathrm{~s}$. The PCR ended with an incubation for $5 \mathrm{~min}$ at $72^{\circ} \mathrm{C}$.

Amplification of the factor IX gene. Purified human genomic DNA served as template for the generation of a 234-bp product from the blood factor IX gene using the previously described primers (17) JR3: 5'-AGG ACC GGG CAT TCT AAG CAG TTT A-3' JR4:
5'-CAG TTT CAA CTT GTT TCA GAG GGA A-3'. The PCR cycle conditions were $94^{\circ} \mathrm{C}$ for $5 \mathrm{~min}$ followed by 40 cycles of $94^{\circ} \mathrm{C}$ for $1 \mathrm{~min} ; 55^{\circ} \mathrm{C}$ for 1 min; and $72^{\circ} \mathrm{C}$ for $1 \mathrm{~min}$. The PCR ended with an incubation for $5 \mathrm{~min}$ at $72^{\circ} \mathrm{C}$. To detect the products, $15 \mu \mathrm{L}$ of the PCR were loaded onto an agarose gel followed by electrophoreses and staining with ethidium bromide.

\section{RESULTS AND DISCUSSION}

\section{Design of the PNA Capture Probe}

Short homopyrimidine PNAs form high-affinity complexes with complementary nucleic acids consisting of two PNAs and one DNA (4). The formation rate of the tri-molecular complex (termed a triplex) is rather slow $(6,8)$ but this rate can be significantly increased by covalently linking the two PNA segments (bisPNA) $(6,8)$ and by including positive charges in the linker segment (8). Based on these reports, we designed the PNA capture probe; BioLys-Gly-TTTTTTT-ado-Lys-Lys-adoTTTTTTT-Lys-NH $\mathrm{N}_{2}$. The probe contains a biotin group that allows the complex between the PNA and its target nucleic acid to be captured by streptavidin-coated magnetic particles. The biotin group is separated from the first PNA segment by a Lys-Gly di-peptide spacer, the two PNA segments are linked by a hybrid spacer molecule containing two positively charged Lysresidues and two ado linkers [8-amino 3,5-dioxaoctanoic acid (20)], and a further lysine residue is placed at the $\mathrm{NH}_{2}$ terminus to increase solubility (14). The $\mathrm{T}_{\mathrm{m}}$ of the complex between the bisPNA $\mathrm{T}_{7}$ and its $\mathrm{A}_{7}$ DNA target sequence was calculated from a melting curve as $63.3^{\circ} \mathrm{C}$.

\section{Analysis of Possible Effects of the bisPNA T $_{7}$ Capture Probe on the PCR}

In the nucleic acid purification method presented here, the entire complex between the paramagnetic streptavidin-coated particles and attached PNA/DNA complex is used directly in the subsequent PCR. Hence, it was important to ascertain that the bisPNA 
$\mathrm{T}_{7}$ did not affect the PCR as previously demonstrated with triplex-forming PNAs $\left(\mathrm{T}_{10}\right.$ and $\left.\mathrm{T}_{9} \mathrm{C}\right)$, which effectively shut down a PCR when bound to target sequences between the two PCR primers (21). Samples of $0.1 \mathrm{pg}$ to 0.1 ng of a plasmid carrying an $\mathrm{A}_{7}$ target sequence on both strands between the PCR primers were amplified in either the absence of bisPNA $\mathrm{T}_{7}$ or in the presence of 25 or $100 \mathrm{pmol}$ of the bisPNA $T_{7}$. As shown in Figure 1, the presence or absence of the bisPNA $\mathrm{T}_{7}$ in the PCR does not appear to change the amount of products generated, indicating that the bisPNA $\mathrm{T}_{7}$ does not affect the PCR. This is probably due to the much reduced thermostability of the bisPNA $\mathrm{T}_{7}$ triplex $\left(\mathrm{T}_{\mathrm{m}}=63.3^{\circ} \mathrm{C}\right)$ compared to the known efficient PCR clamping triplexes PNA $\mathrm{T}_{10}\left(\mathrm{~T}_{\mathrm{m}}=\right.$ $\left.76^{\circ} \mathrm{C}\right)$ and $\mathrm{PNA} \mathrm{T}_{9} \mathrm{C}\left(\mathrm{T}_{\mathrm{m}}=79^{\circ} \mathrm{C}\right)(21)$.

\section{Purification of Human Genomic DNA from Whole Blood}

The ability of the bisPNA $\mathrm{T}_{7}$ to capture nucleic acids from biological samples was analyzed using whole blood obtained by venapuncture in EDTA buffer. A $50-\mu \mathrm{L}$ blood sample was lysed in a total volume of $200 \mu \mathrm{L}$ as described in Materials and Methods. Aliqouts of the lysate corresponding to 1,5 and $10 \mu \mathrm{L}$ of blood were then used either directly as templates for PCR amplification of the CFTR gene or taken through the purification procedure in the presence or absence of the bisPNA $\mathrm{T}_{7}$ before amplification. When the lysate is purified in the presence of the bisPNA $\mathrm{T}_{7}$ capture probe, a product can be detected in all cases (Figure 2, lane 2-4). No products are detected when the bisPNA $T_{7}$ is omitted from the purification procedure (lane 5) or in the control reaction where blood is omitted (lane 6). Also, consistent with previous reports, which conclude that even very small amounts of blood contain potent inhibitors of the PCR $(2,11,15,16)$, we do not detect products when amplifications are conducted directly on the unpurified lysate (lanes 7-9). To ascertain that the absence of products in the direct PCRs on unpurified lysate were not caused by incomplete heat-inactivation of proteinase $\mathrm{K}$ from the lysis step, we performed a series of control reactions. When proteinase $\mathrm{K}$ was added to dilution series of purified human genomic DNA, no products could be detected after amplification when the heat-inactivation step was omitted. When the heat-inactivation step was included, however, all PCRs generated products in an amount comparable to the similar reactions where proteinase $\mathrm{K}$ was not included (data not shown).

We conclude that the bisPNA $\mathrm{T}_{7}$ facilitates efficient capture of human genomic DNA and that the purification scheme effectively removes the PCR inhibitors present in the crude blood lysate.

The above experiment with EDTAbuffered blood was repeated with blood in which sodium citrate or heparin was used as anticoagulant. Sodium citrate blood produced results similar to the EDTA blood, whereas amplification of DNA purified from heparin blood was repeatedly lower (approximately 3 times lower intensity of the ethidium bromide-stained products in the gel).

\section{Sample Preparation of Different Amounts of Whole Blood}

Blood is often used as the starting sample for the detection of pathogens such as viruses and bacteria that can be present in very low copy numbers. Hence, a useful diagnostic samplepreparation method should allow significant amounts of starting samples to be handled.

To determine the limits of the PNA sample-preparation method, the assay was performed with amounts of blood ranging from $0.001-500 \mu \mathrm{L}$. As before, the PCRs were performed with the primers against the CFTR gene. As shown in Figure 3, the lower limit of detection by gel analysis is $1 \mu \mathrm{L}$ of blood (lane 7). For more than $1 \mu \mathrm{L}$ of blood, all PCRs produce products, and from 10-500 $\mu \mathrm{L}$ of blood, a consistent strong signal is visible in the gel (lanes $2-5)$. We conclude that $500 \mu \mathrm{L}$ of whole blood is within the range that can be handled by the method and that still larger volumes are probably also feasible.

\section{Purification of DNA from Blood from a Range of Different Donors}

To validate that the PNA purifica-

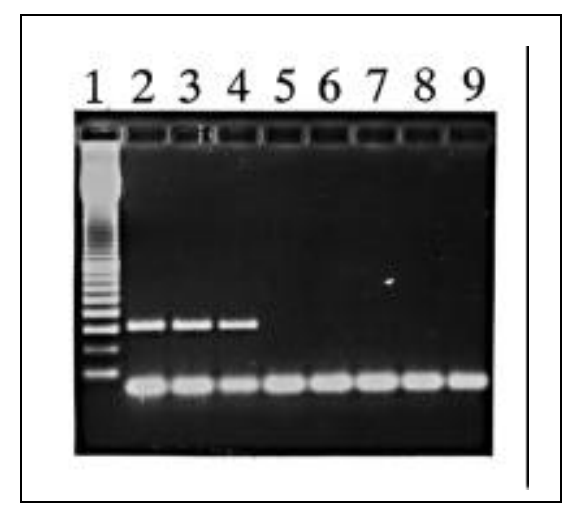

Figure 2. Amplification of DNA purified from whole blood. Lane 1:100-bp ladder. Sample preparation with bisPNA $\mathrm{T}_{7}$ on aliquots corresponding to 1 (lane 2), 5 (lane 3) and $10 \mu \mathrm{L}$ (lane 4) of whole blood. Lane 5: sample preparation without PNA on an aliquot corresponding to 10 $\mu \mathrm{L}$ of whole blood. Lane 6: sample preparation with bisPNA $\mathrm{T}_{7}$ but without blood. Direct PCR on aliqouts of lysate corresponding to 1 (lane 7), 5 (lane 8 ) and $10 \mu \mathrm{L}$ (lane 9) of whole blood.
Figure 1. Amplification of plasmid in the presence and absence of the bisPNA-T $\mathbf{T}_{7}$. Lane 1:100-bp ladder. Without plasmid template and with 0 (lane 2), 25 (lane 3) or 100 pmol (lane 4) of bisPNA $\mathrm{T}_{7}$. Lanes 5-7: same as lanes 2-4 but with $0.1 \mathrm{ng}$ of plasmid template; lanes 8-10: (10 pg of plasmid template); lanes 11-13: (1 pg of plasmid template) and lanes 14-16: (0.1 pg of plasmid template). 


\section{Research Reports}

tion method applies to blood samples in general, we expanded the analysis to include blood samples from 12 different donors ( 6 male and 6 female). Furthermore, DNA purified from each donor was subjected to three different PCRs aimed at different regions in the human genome; CFTR, chromosome 7 (18); blood factor IX, X-chromosome (17); and variable number tandem repeat (VNTR), chromosome 1 (12). The analysis was conducted with $50 \mu \mathrm{L}$ of whole blood. Figure 4 shows the result of amplification of the factor IX gene, which in all 12 cases analyzed generates products of the expected sizes. Similar results were obtained when either the CFTR gene or the VNTR region (PCR conditions according to Reference 9) was used as target for amplification (data not shown).

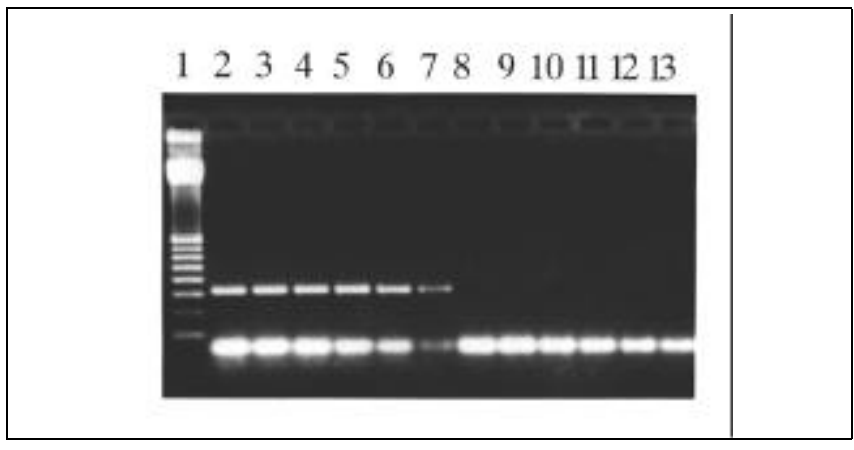

Figure 3. Amplification of the CFTR gene using purified genomic DNA from different amounts of whole blood. Lane 1:100-bp ladder. Lanes 2-12: sample preparation with bisPNA- $\mathrm{T}_{7}$ using 500, 250,100, 50, 10, 1, 0.5, 0.1, $0.01,0.001$ and $0 \mu \mathrm{L}$ of whole blood, respectively. Lane 13: sample preparation without PNA using $50 \mu \mathrm{L}$ of whole blood.

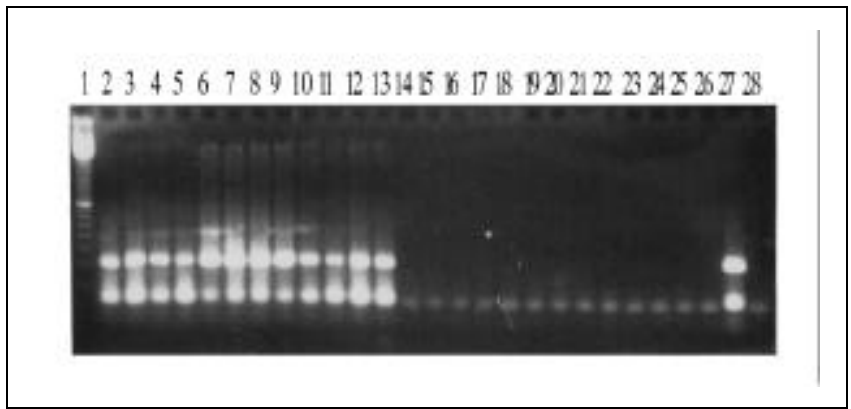

Figure 4. Amplification of the factor IX gene using purified genomic DNA from 12 different donors. Lane 1:100-bp ladder. Lanes 2-7: sample preparation with bisPNA $\mathrm{T}_{7}$ using $50 \mu \mathrm{L}$ of whole blood from the 6 female donors. Lanes 8-13: same as lanes 2-7 but using the 6 male donors. Lanes 14-26: same as lanes $2-13$ but without the bisPNA-T ${ }_{7}$. Lane 27: positive PCR control. Lane 28: negative PCR control. 
These data strongly suggest that the method is generally applicable to the purification of human genomic DNA and that it allows purification of the different chromosomes.

\section{CONCLUSION}

We have shown that a bisPNA $\mathrm{T}_{7}$ is effective in the purification of human genomic DNA from volumes as much as $500 \mu \mathrm{L}$ of whole blood and that the resulting DNA can be amplified by PCR. The method does not involve hazardous chemicals and should be relatively straightforward to automate. The advantage of the method is that it allows nucleic acids to be purified by hybridization even in cases where no sequence information on the target nucleic acid is available. In contrast to the previously described DNA purification method $(1,22)$, which uses sequencespecific, duplex-forming PNA probes, the triplex-based method described here does not allow individual target molecules to be purified from bulk nucleic acids. Hence, the new method does not replace, but rather complements, the previously described method to increase the versatility of the concept of purification by hybridization.

\section{REFERENCES}

1.Borre, M.B., M. Naesby and H. Ørum. 1997. PNA used for specific capture of nucleic acids, p. 61-72. In B. Schaefer (Ed.), Gene Cloning and Analysis: Current Innovations. Horizen Scientific Press, Wymondham, UK.

2.Debomoy, K.L., S. Bye, Jr., J.I. Nurnberger, M.E. Hodes and M. Crisp. 1992. A non-organic and non-enzymatic extraction method gives higher yields of genomic DNA from whole-blood samples than do nine other methods tested. J. Biochem. Biophys. Methods 25:193-205.

3.Dieffenbach C.W. and G.S. Dveksler. 1995. PCR Primer: A Laboratory Manual. CSH Laboratory Press, Cold Spring Harbor, NY.

4.Egholm, M., P.E. Nielsen, O. Buchardt and R.H. Berg. 1992. Recognition of guanine and adenine in DNA by cytosine and thymine containing peptide nucleic acids (PNA). J. Am. Chem. Soc. 114:9677-9678.

5.Egholm, M., C. Behrens, L. Christensen, R.H. Berg, E.E. Nielsen and O. Buchardt. 1993. Peptide nucleic acids containing adenine or guanine recognise thymine and cytosine in complementary DNA sequences. J. Chem. Soc. Chem. Commun. 9:800-801.

6.Egholm, M., L. Christensen, K.L. Dueholm, O. Buchardt, J. Coull and P.E. Nielsen.
1995. Efficient pH-independent sequence-specific DNA binding by pseudoisocytosine-containing bis-PNA. Nucleic Acids Res. 23:217222.

7.Greenfield, L. and T.J. Write. 1993. Sample preparation methods, p. 122-137. In D.H. Persing, T.F. Smidt, F.C. Tenover and T.J. Write (Eds.), Diagnostic Molecular Biology: Principles and Applications. American Society for Microbiology, Washington, D.C.

8.Griffith, M.C., L.M. Risen, M.J. Greig, E.A. Lesnik, K.G. Sprankle, R.H. Griffey, J.S. Kiely and S.M. Freier. 1995. Single and bis peptide nucleic acids as triplexing agents: binding and stoichiometry. J. Am. Chem. Soc. 117:831-832.

9.Kasai, K., Y. Nakamura and R. White. 1990. Amplification of a variable number of tandem repeats (VNTR) locus (pMCT118) by the polymerase chain reaction (PCR) and its application to forensic science. J. Forensic Sci. 35:1196-1200.

10.Koch. T, H.F. Hansen, P. Andersen, T. Larsen, H.G. Batz, K. Otteson and H. Ørum. 1997. Improvements in automated PNA synthesis using Boc/Z monomers. J. Peptide Protein Res. 49:80-88.

11.Mercier, B., C. Gaucher, O. Feugeas and C. Mazurier. 1990. Direct PCR from whole blood, without DNA extration. Nucleic Acids Res. 18:5908.

12.Nakamura, Y., M. Carlson, K. Krapcho and R. Write. 1988. Isolation and mapping of a polymorphic DNA sequence, pMCT118 on chromosome 1p (D1S58). Nucleic Acids Res. 16:9364.

13.Nielsen, P.E., M. Egholm, R.H. Berg and O. Buchardt. 1991. Sequence selective recognition of DNA by strand displacement with a thymine-substituted polyamide. Science 254:1497-1500.

14.Noble, S.A., M.A. Bonham, J.E. Bisi, D.A. Bruckenstein, P.H. Brown, S.C. Brown, R. Cadilla, M.D. Gaul et al. 1995. Impact of biophysical parameters on the biological assessment of peptide nucleic acids, antisense inhibitors of the gene expression. Drug Dev. Res. 34:184-195.

15.Panaccio, M. and A. Lew. 1991. PCR based diagnosis in the presence of $8 \%$ ( $\mathrm{vol} / \mathrm{vol}$ ) blood. Nucleic Acids Res. 19:1151.

16.Panaccio, M., M. Georgesz and A.M. Lew. 1993. FoLT PCR: A simple PCR protocol for amplifying DNA directly from whole blood. BioTechniques 14:238-243.

17.Reiss, J., U. Neufeldt, K. Wieland and B. Zoll. 1990. Diagnosis of haemophilia B using the polymerase chain reaction. Blut 60:31-36.

18.Riordan, J.R., J.M. Rommens, B. Kerem, N. Alon, R. Rozmahel, Z. Grzelczak, J. Zielenski, S. Lok et al. 1989. Identification of the cystic fibrosis gene: cloning and characterization of complementary DNA. Science 245:1066-1072.

19.Rossen, L., P. Norskov, K. Holmstrom and O.F. Rasmussen. 1992. Inhibition of PCR by components of food samples, microbial diagnostic assays and DNA extraction solutions. Int. J. Food Microbiol. 17:37-45.

20.Rumney, S., IV. and E.T. Kool. 1995. Structural optimization of non-nucleotide loop replacement for duplex and triplex DNAs. J.
Am. Chem.Soc. 117:5635-5646.

21.Ørum, H., P.E Nielsen, M. Egholm, R.H. Berg, O. Buchardt and S. Stanley. 1993. Single base pair mutation analysis by PNA directed PCR clamping. Nucleic Acids Res. 21:5332-5336.

22.Ørum, H., P.E. Nielsen, M. Jørgensen, C. Larsson, C. Stanley and T. Koch. 1995. Sequence-specific purification of nucleic acids by PNA-controlled hybrid selection. BioTechniques 19:472-480.

Received 4 December 1996; accepted 14 April 1997.

Address correspondence to:

Corina Seeger

PNA Diagnostics A/S

Rønnegade 2, 6th floor

DK-2100

Copenhagen $\varnothing$, Denmark 